\title{
Character Association Studies in Sorghum [Sorghum bicolor (L.) Moench] Germplasm Lines for Shoot Fly Resistance Parameters
}

\author{
A.J. Syed*, A.W. More and H.V. Kalpande \\ Sorghum Research Station, Vasantrao Naik Marathwada Krishi Vidyapeeth, \\ Parbhani-431 402, Maharashtra, India \\ *Corresponding author
}

\section{A B S T R A C T}

Ke y w o r d s
Correlation,
Sorghum, Shootfly,
Variability.

Sorghum shoot fly (Atherigona soccata Rond.) one of the major constraints in sorghum production and host plant resistant is one of the component to control to sorghum shoot fly. The present study was carried out with hundred and sixteen Sorghum germplasm lines and four checks one resistant check, one susceptible check and two varietal checks. Observation were recorded on the characters viz., deadheart percentage, trichome density, leaf glossiness, seedling vigour, leaf wetness, Plumule and leaf sheath pigmentation, chlorophyll content, plant height, leaf length, leaf breadth, leaf angle, days to 50\% flowering, days to maturity, 100 seed weight and grain yield per plant. The data were collected and analyzed for correlation. The characters leaf glossiness, seedling vigour, leaf wetness and chlorophyll content were significant and positively correlated with deadheart percentage at $28 \mathrm{DAE}$ at both the genotypic and phenotypic levels. Whereas, trichome density (adaxial and abaxial), plant height, leaf length, leaf breadth and grain yield per plant has recorded negative significant association with dead heart percentage at $28 \mathrm{DAE}$ at both genotypic and phenotypic level. While, 100 seed weight has significant but negative correlation with dead heart percentage at 28 DAE at genotypic level only.

\section{Introduction}

Sorghum [Sorghum bicolor (L.) Moench] is the fifth most important cereal crop globally after rice, maize, wheat and barley (FAO 2004). It is predominantly cultivated in semiarid tropics (SAT) and is the dietary staple of more than 500 million people in 30 countries. The yield penalties to sorghum is very high starting from seedling stages to marketing, and the maximum losses is caused due to biotic stress.. Sorghum is damaged by 150 insect pests from seedling to harvesting stage (Seshu Reddy and Davis, 1978; Jotwani et al., 1980; Sharma, 1985). Out of which 31 species are economically important. Out of these species, Shoot fly (Atherigona soccata Rond.) assumed the most important pest. Status in the states in general and rabi in particular indicates that, the losses due to this pest have been estimated to reach as high as 86 per cent of grain and 46 per cent of fodder yield. Losses caused by this pest vary with the pest population, season of sowing and nature of cultivars. Host plant resistance is one of the most effective means of keeping shoot fly population below economic threshold levels, as it does not involve any cost input by the farmers. Hence, it is important to identify the genotypes with different mechanisms to 
increase the levels and diversify the bases of resistance to this insect. Therefore, the present study was carried out on a diverse array of sorghum genotypes to identify resistant sources and plant characteristics influencing resistance/susceptibility to shoot fly (Atherigona soccata).

\section{Materials and Methods}

The material used for this study was comprised of 116 genotypes and four checks (One resistant check IS-18851, one susceptible check DJ-6514 and two varietal checks SPV-1411 and PVK-801). Experiment was conducted in Randomized Block Design (RBD) with two replications during rabi 2015-16 at Sorghum Research Station, Vasantrao Naik Marathwada Krishi Vidyapeeth, Parbhani. Each genotype was sown in two rows of $4 \mathrm{~m}$ length with spacing of $0.45 \mathrm{~m}$ and $0.15 \mathrm{~m}$ between rows and within plants was adopted. All the agronomical practices were followed to raise good crop. Data was recorded on twelve shootfly resistant associated traits viz., Plant height, leaf length, leaf breadth, seedling vigour, glossiness score, leaf wetness, dead heart at 14 and 28 days after sowing, trichome density at abaxial and adaxial surface, days to $50 \%$ flowering, 100 seed weight (gm) and grain yield par plant (gm). Five plants at random in each plot and replication were chosen and labeled for recording observations and the mean of five plants was used for statistical analysis. The analysis of variance was done as suggested by Panse and Sukhatme (1967) and correlation studies were carried out as suggested by Johnson et al., (1955).

\section{Results and Discussion}

The correlation coefficient was studied in order to find out the association of morphological traits with expression of Shoot fly (Atherigona soccata) at genotypic and phenotypic levels. The genotypic and phenotypic correlation coefficients for thirteen characters are presented in Table 1 revealed that, genotypic correlations were of higher magnitude than the phenotypic correlations indicating the inherent association between various traits. Association of deadheart percentage at 14 DAE was highly significant and positive with deadheart percentage at 28 DAE $(\mathrm{G}=0.918$, $\mathrm{P}=0.861)$, leaf glossiness $(\mathrm{G}=0.784, \mathrm{P}=0.642)$, seedling vigour $(\mathrm{G}=0.672, \mathrm{P}=0.543)$ and leaf wetness $(\mathrm{G}=0.627, \quad \mathrm{P}=0.521)$ at both genotypic and phenotypic level. Trichome density at adaxial $(\mathrm{G}=-0.441, \mathrm{P}=-0.416)$ and abaxial leaf surface $(\mathrm{G}=-0.715, \mathrm{P}=-0.672)$, plant height $(\mathrm{G}=-0.186, \mathrm{P}=-0.176)$, leaf length $(\mathrm{G}=-0.183, \mathrm{P}=-157)$ and grain yield per plant $(\mathrm{G}=-225, \quad \mathrm{P}=-195)$ showed significant but negative association with dead heart percentage at $14 \mathrm{DAE}$ at both the levels and leaf breadth $(\mathrm{G}=-0.136)$ recorded significant negative association at genotypic level. Kalpande et al., 2015 observed the significant and negative correlation between trichome density (both the surface of leaf laming) and leaf glossiness with shoot fly oviposition as well as dead hearts.

The characters leaf glossiness $(\mathrm{G}=0.776$, $\mathrm{P}=0.699)$, seedling vigour $(\mathrm{G}=0.763$, $\mathrm{P}=0.638)$, leaf wetness $(\mathrm{G}=0.704, \mathrm{P}=0.593)$ and chlorophyll content $(\mathrm{G}=0.433, \mathrm{P}=0.409)$ were significantly and positively correlated with deadheart percentage at $28 \mathrm{DAE}$ at both the genotypic and phenotypic levels. Whereas, trichome density (adaxial) ( $\mathrm{G}=$ 0.486, $\mathrm{P}=-0.476$ ), trichome density (abaxial) $(\mathrm{G}=-0.733, \quad \mathrm{P}=-0.717)$, plant height $(\mathrm{G}=-$ $0.192, \mathrm{P}=-0.185)$, leaf length $(\mathrm{G}=-0.237, \mathrm{P}=$ $0.219)$, leaf breadth $(\mathrm{G}=-0.164, \mathrm{P}=-0.150)$ and grain yield per plant $(\mathrm{G}=-0235, \mathrm{P}=-0.205)$ had recorded negative significant association with dead heart percentage at $28 \mathrm{DAE}$ at both genotypic and phenotypic level. 
Table.1 Genotypic and phenotypic correlation coefficient for thirteen shoot fly resistant characters

\begin{tabular}{|c|c|c|c|c|c|c|c|c|c|c|c|c|c|c|}
\hline Characters & & $\begin{array}{c}\text { Deadheart } \\
14 \text { DAE }\end{array}$ & $\begin{array}{c}\text { Deadheart } \\
28 \text { DAE }\end{array}$ & $\begin{array}{l}\text { Trichome } \\
\text { (Adaxial) }\end{array}$ & $\begin{array}{l}\text { Trichome } \\
\text { (Abaxial) }\end{array}$ & $\begin{array}{c}\text { Leaf } \\
\text { Glossiness }\end{array}$ & $\begin{array}{c}\text { Seedling } \\
\text { Vigour }\end{array}$ & $\begin{array}{c}\text { Leaf } \\
\text { Wetness }\end{array}$ & $\begin{array}{c}\text { Plant } \\
\text { height }\end{array}$ & $\begin{array}{c}\text { Leaf } \\
\text { length }\end{array}$ & $\begin{array}{c}\text { Leaf } \\
\text { breadth }\end{array}$ & $\begin{array}{l}\text { Days to } 50 \% \\
\text { flowering }\end{array}$ & $\begin{array}{c}100 \\
\text { Seed wt. }\end{array}$ & $\begin{array}{c}\text { Grain } \\
\text { yield/plant }\end{array}$ \\
\hline \multirow{2}{*}{$\begin{array}{l}\text { Deadheart } 14 \\
\text { DAE }\end{array}$} & $\mathrm{G}$ & 1.000 & $0.918 * *$ & $-0.441 * *$ & $-0.715^{* *}$ & $0.748 * *$ & $0.672 * *$ & $0.627 * *$ & $-0.186^{* * *}$ & $-0.183 * *$ & $-0.136^{*}$ & -0.081 & -0.101 & $-0.225^{* *}$ \\
\hline & $\mathrm{P}$ & 1.000 & $0.861 * *$ & $-0.416 * *$ & $-0.672 * *$ & $0.642 * *$ & $0.543 * *$ & $0.521 * *$ & $-0.176^{* * *}$ & $-0.157^{*}$ & -0.112 & -0.077 & -0.067 & $-0.195^{* *}$ \\
\hline \multirow{2}{*}{$\begin{array}{l}\text { Deadheart } 28 \\
\text { DAE }\end{array}$} & $\mathrm{G}$ & & 1.000 & $-0.486 * *$ & $-0.733 * *$ & $0.776^{* *}$ & $0.763 * *$ & $0.704 * *$ & $-0.192 * *$ & $-0.237 * *$ & $-0.164 *$ & -0.082 & $-0.151^{*}$ & $-0.235 * *$ \\
\hline & $\mathrm{P}$ & & 1.000 & $-0.476 * *$ & $-0.717 * *$ & $0.699 * *$ & $0.638^{* *}$ & $0.593 * *$ & $-0.185^{* * *}$ & $-0.219 * *$ & $-0.150^{*}$ & -0.077 & -0.126 & $-0.205^{* *}$ \\
\hline \multirow{2}{*}{$\begin{array}{l}\text { Trichome } \\
\text { (Adaxial) }\end{array}$} & $\mathrm{G}$ & & & 1.000 & $0.548^{* *}$ & $-0.341^{* *}$ & $-0.336^{* *}$ & $-0.332 * *$ & $0.129^{*}$ & $0.133^{*}$ & 0.089 & 0.125 & 0.110 & 0.038 \\
\hline & $\mathrm{P}$ & & & 1.000 & $0.547^{* *}$ & $-0.314 * *$ & $-0.292 * *$ & $-0.286^{* *}$ & 0.126 & $0.127 *$ & 0.086 & 0.120 & 0.102 & 0.034 \\
\hline \multirow{2}{*}{$\begin{array}{l}\text { Trichome } \\
\text { (Abaxial) }\end{array}$} & $\mathrm{G}$ & & & & 1.000 & $-0.543 * *$ & $-0.520^{* *}$ & $-0.476^{* *}$ & $0.155^{*}$ & $0.178 * *$ & $0.184^{* *}$ & $0.154^{*}$ & $0.157^{*}$ & 0.100 \\
\hline & $\mathrm{P}$ & & & & 1.000 & $-0.498 * *$ & $-0.449 * *$ & $-0.411 * *$ & $0.154^{*}$ & $0.170^{* *}$ & $0.173 * *$ & $0.148^{*}$ & $0.146^{*}$ & 0.091 \\
\hline \multirow{2}{*}{$\begin{array}{l}\text { Leaf } \\
\text { Glossiness }\end{array}$} & $\mathrm{G}$ & & & & & 1.000 & $0.888^{* *}$ & $0.780 * *$ & $-0.256^{* * *}$ & $-0.199 * *$ & $-0.224 * *$ & 0.027 & -0.033 & $-0.190^{* *}$ \\
\hline & $\mathrm{P}$ & & & & & 1.000 & $0.690 * *$ & $0.585 * *$ & $-0.231 * *$ & $-0.196 * *$ & $-0.213 * *$ & 0.036 & -0.036 & $-0.156^{*}$ \\
\hline \multirow{2}{*}{$\begin{array}{l}\text { Seedling } \\
\text { Vigour }\end{array}$} & $\mathrm{G}$ & & & & & & 1.000 & $0.858 * *$ & $-0.259 * *$ & $-0.215^{* *}$ & -0.311 ** & 0.086 & $-0.174 * *$ & $-0.220 * *$ \\
\hline & $\mathrm{P}$ & & & & & & 1.000 & $0.692 * *$ & $-0.229 * *$ & $-0.157^{*}$ & $-0.272 * *$ & 0.052 & $-0.129 *$ & $-0.143^{*}$ \\
\hline Leaf Wetness & $\mathrm{G}$ & & & & & & & 1.000 & $-0.186^{* *}$ & $-0.140^{*}$ & $-0.329 * *$ & $0.200 * *$ & -0.092 & $-0.254 * *$ \\
\hline \multirow{2}{*}{ Plant Height } & $\mathrm{G}$ & & & & & & & & 1.000 & $0.366^{* *}$ & $0.480 * *$ & 0.071 & $0.152^{*}$ & $0.128 *$ \\
\hline & $\mathrm{P}$ & & & & & & & & 1.000 & $0.348 * *$ & $0.453 * *$ & 0.068 & $0.134^{*}$ & 0.114 \\
\hline \multirow{2}{*}{ Leaf length } & $\mathrm{G}$ & & & & & & & & & 1.000 & $0.436^{* *}$ & 0.054 & $0.218^{* *}$ & $0.239 * *$ \\
\hline & $\mathrm{P}$ & & & & & & & & & 1.000 & $0.397 * *$ & 0.046 & $0.202 * *$ & -0.001 \\
\hline \multirow{2}{*}{ Leaf breadth } & $\mathrm{G}$ & & & & & & & & & & 1.000 & 0.037 & $0.172^{* * *}$ & $0.239 * *$ \\
\hline & $\mathrm{P}$ & & & & & & & & & & 1.000 & 0.046 & $0.154^{*}$ & $0.183^{* *}$ \\
\hline \multirow{2}{*}{$\begin{array}{l}\text { Days to } 50 \% \\
\text { flowering }\end{array}$} & G & & & & & & & & & & & 1.000 & 0.010 & -0.056 \\
\hline & $\mathrm{P}$ & & & & & & & & & & & 1.000 & -0.006 & -0.062 \\
\hline \multirow{2}{*}{$\begin{array}{l}\text { Seed Weight } \\
100 \text { seed wt. }\end{array}$} & G & & & & & & & & & & & & 1.000 & $0.306^{*}$ \\
\hline & $\mathrm{P}$ & & & & & & & & & & & & 1.000 & $0.267 *$ \\
\hline
\end{tabular}


100 seed weight $(\mathrm{G}=-0.151)$ has significant but negative correlation with dead heart percentage at $28 \mathrm{DAE}$ at genotypic level.

Association of trichome density both at adaxial and abaxial surface was highly significant and positive with plant height ( $\mathrm{G}=0.155, \mathrm{P}=0.154)$, leaf length $(\mathrm{G}=0.178$, $\mathrm{P}=0.170)$, leaf breadth $(\mathrm{G}=0.184, \mathrm{P}=0.173)$, days to $50 \%$ flowering $(\mathrm{G}=0.154, \mathrm{P}=0.148)$ and 100 seed weight $(\mathrm{G}=0.157, \mathrm{P}=0.146)$ at genotypic and phenotypic levels. The trait leaf glossiness $(\mathrm{G}=-0.543, \quad \mathrm{P}=-0.498)$, seedling vigour $(\mathrm{G}=-0.520, \mathrm{P}=-449)$ and leaf wetness $(\mathrm{G}=-0.476, \mathrm{P}=-0.411)$ was found significant but negative association with trichome density (abaxial) at both genotypic and phenotypic level. Dhillon et al., (2005) also reported that the correlation coefficients of leaf glossiness, leaf surface, wetness and leaf sheath pigmentation were significant and positive for eggplant-1 and deadhearts while for trichome density, these correlation coefficients where significant and negative.

Association of days to $50 \%$ flowering showed negative but significant association with grain yield per plant $(\mathrm{G}=-0.148, \mathrm{P}=-0.130)$ at genotypic and phenotypic level. While 100 seed weight was recorded significant and positive correlation with grain yield per plant $(\mathrm{G}=0.306, \mathrm{P}=0.267)$ at both genotypic and phenotypic level. These results are in close proximity with the earlier researchers findings Omori et al.,(1983), Sing et al., (2004), Dhillon et al., (2006), Gomashe et al., (2010), Kamatar et al., (2010), Riyazaddin et al., (2016).

Raina (1985) reported that trichomes may contribute to the expression of antibiosis to shootfly in sorghum as trichomed cultivars hinder the movement of newly hatched larval to the base of the whorl. Trichomes on both the surface of leaf lamina and leaf glossiness played important role in shoot fly resistance
(Gomashe et al., 2010; Dhillon et al., 2005). This suggests while selecting for improvement in shoot fly resistance traits these characters can be kept in mind provided the character should show high variability, which is basis for selection.

\section{References}

Dhillon M.K., Sharma H.C., Reddy B. V. S., Sing Ram.., and Naresh J.S., 2006. Inheritance of Resistance to Sorghum Shoot Fly, Atherigona soccata. CROP SCIENCE, VOL. 46:1377-1383.

Dhillon, M.K., Sharma, H.C., Ram Sing, and Naresh, J.S., 2005.Mechanism of resistance to shoot Fly (Atherigona soccata) in sorghum.Euphytica 144: 301-312.

FAO, 2014. Food and Agriculture Organization of the United Nations. http://faostat.fao.org/default.aspx.

Gomashe S., Misal, M.B., Ganapathy, K.N., and Sujay Rakshit. 2010. Correlation studies for shootfly resistance traits in sorghum (Sorghum bicolor (L.) Moench). Electronic Journal of Plant Breeding, 1(4): 899-902.

Johnson, R.E., Robinson, H.W., and Comstock, H.F., 1955. Estimates of genetic and environmental variability in Soybean. Agrono. J. 47: 314-318.

Jotwani M. G., and Davies J. C., 1980 Insect resistance studies in sorghum at International Institutes and National Programs with special reference to India. pp 224-236. In Proceedings of the short course Sharma 1985 in host plant resistance (ed M K Harris). Texas A \& M University, College Station, Texas, USA.

Kalpande, V.V., Sakhare, B.A., Ghorade, R.B. and Lad, A.P.2015. Potential parents for yield and its component traits in rabi sorghum. The Bioscan.10 (2): 837-839, 2015. 
Kamatar, M.Y., Patil, A.M., Arati Yadwad, Salimath P.M., and Swamy Rao T., 2010. Correlation and path analysis in parents and hybrids for resistance to sorghum shoot fly Atherigona soccata (Rondani) International Journal of Plant Sciences, Vol. 5 Issue 2: 399-403.

Omori, T., Agrawal B.L., and House, L.R., 1983. Componental analysis of the factors influencing shoot fly resistance in sorghum [Sorghum bicolor (L.) Moench] Atherigona soccata J. ARQ. 17: 2 15-218.

Panse, V.G., and Sukhatme, P.V., 1967. Statistical methods for Agricultural workers $2^{\text {nd }}$ edn. pp/381, I.C.A.R., New Delhi.

Raina, A.K., 1985. Mechanisms of resistance to shoot fly (Atherigona soccata) in sorghum: a review. Proceedings of the International Sorghum Entonlology Workshop. 15-21 July 1984. Texas A \&
M University. College Station. TX, USA, pp. 131-136.

Riyazaddin Mohammed, Rajendra S. Munghat, Ashok Kumar Are, Kavi Kishor B. Polavarapu, Belum V. S. Reddy, Hari C. Sharma. 2016. Components of resistance to sorghum shoot fly, Atherigona Soccata. Euphytica, 207:419-438.

Seshu Reddy K. V. and Davies J. C. I978. Species of Atherigona. Andhra Pradesh. PANS 23:379-383.

Sharma H.C., 1985. Future strategies for pest control in sorghum in India. Trop Pest Manag 31:167-185

Sing, B.U., Padmaja, P.G., Seetharama N., 2004. Stability of biochemical constituents and their relationships with resistance to shoot fly (Atherigona soccata (Rondoni) in seedling sorghum. Euphytica 136:279-289.

\section{How to cite this article:}

Syed, A.J., A.W. More and Kalpande, H.V. 2017. Character Association Studies in Sorghum [Sorghum bicolor (L.) Moench] Germplasm Lines for Shoot Fly Resistance Parameters. Int.J.Curr.Microbiol.App.Sci. 6(12): 298-302. doi: https://doi.org/10.20546/ijcmas.2017.612.035 